\title{
Creating dance with bytes and pixels
}

\author{
Citation for published version (APA):
}

Anker, V. (2020). Creating dance with bytes and pixels: technologies as mediators in digital performance rehearsals. [Doctoral Thesis, Maastricht University]. ProefschriftMaken.

https://doi.org/10.26481/dis.20200212va

Document status and date:

Published: 01/01/2020

DOI:

10.26481/dis.20200212va

Document Version:

Publisher's PDF, also known as Version of record

\section{Please check the document version of this publication:}

- A submitted manuscript is the version of the article upon submission and before peer-review. There can be important differences between the submitted version and the official published version of record.

People interested in the research are advised to contact the author for the final version of the publication, or visit the DOI to the publisher's website.

- The final author version and the galley proof are versions of the publication after peer review.

- The final published version features the final layout of the paper including the volume, issue and page numbers.

Link to publication

\footnotetext{
General rights rights.

- You may freely distribute the URL identifying the publication in the public portal. please follow below link for the End User Agreement:

www.umlib.nl/taverne-license

Take down policy

If you believe that this document breaches copyright please contact us at:

repository@maastrichtuniversity.nl

providing details and we will investigate your claim.
}

Copyright and moral rights for the publications made accessible in the public portal are retained by the authors and/or other copyright owners and it is a condition of accessing publications that users recognise and abide by the legal requirements associated with these

- Users may download and print one copy of any publication from the public portal for the purpose of private study or research.

- You may not further distribute the material or use it for any profit-making activity or commercial gain

If the publication is distributed under the terms of Article $25 \mathrm{fa}$ of the Dutch Copyright Act, indicated by the "Taverne" license above, 


\section{Summary}

In this thesis I study processes of digital dance creation through the lens of technological mediation theory. With this approach I intend to draw an alternative view on choreotechnological constellations that differs from conventional positions in which the relations between dance and digital media are described in terms of opposition and domination. In this sense I follow selected researchers in the digital performance field who propose to avoid one-sided accounts on digital dance with the help of a more relational understanding of technology. The questions that this study ultimately sets out to answer are: How do dance artists and digital media collaborate in the creation of digital dance performances? What is technology's role in these processes? And how can the dynamics of these procedures be qualified? Instead of departing from perspectives of separation and alterity between dance art on the one hand and media on the other, I focus on their interwoven and situative condition. I therefore base my study on a definition of (digital) technology that derives from the field of Science and Technology Studies (STS). In STS, technology is not understood in terms of material artefacts only, but also in terms of socio-technical constellations. This means that scholars in STS consider technology as already being embedded in socio-cultural contexts. In this view, technologies thus cannot be clearly separated from human and social processes. Here, STS-related theories on technology's mediating character lead me to suggest that understanding digital dance making as processes of mediation allows to closely examine the complex dynamics of virtual performance. In this research project I thus propose to relate selected approaches of mediation from the field of STS, such as Actor-Network Theory and postphenomenology, and concepts form performance studies to the current scholarship on digital performance.

This project embraces digital dance's empirical reality by looking at concrete practices in which dance artists and virtual tools enter in contact, negotiate and finally mingle. It focuses on the making of two virtual performance artworks: loopdiver (2009) by the American dance group Troika Ranch, and Habitat (2010), a production by the German artistic collective LaborGras. By delving into how digital dance artists negotiate the grey zones between dance and new media, this thesis addresses the concrete challenges digital dance makers are confronted with when they develop, rehearse and perform digital performance productions. Moving between the detailed and material processes of the pieces' makings and my interdisciplinary theoretical tools, in this thesis I develop empirically sensitive models to understand technology's role in digital dance production. Guided by the urgency and relevance in both artistic practice and digital dance discourse, I specifically focus on the creative dynamics between dance artists and 
digital tools as well as on the formation of the dancers' physical experience in their interaction with digital media. In the context of the first focal point, I formulate the following sub-questions: In which ways can technological tools engage in the artistic dynamics of dance creation? And how precisely can this involvement co-shape artistic intentions and the resulting performances? To explore the second centre of interest, I ask: How do media integrate bodily experience in (digital) dance?

Exploring how dance artists deal with virtual media in virtual performance making, this dissertation takes an empirical approach. I specifically conducted ethnographic research methodologies like interviewing and participant observation in a technographic perspective. This means that I not only followed the human actors such as dance artists, multimedia programmers or technicians but I also examined in which ways the technological tools were relating to the observed activities.

After introducing the field of digital dance and the research design, I will show in chapter 2 that both digital performance practitioners and scholars demonstrate biased stances concerning technology's role in virtual performance creation. These perspectives, I argue, are incompatible with the empirical reality of digital dance making because they do not recognize any creative agency to digital devices. To develop a differentiated conceptual view on how digital media integrate the artistic aspects of digital dance production, I start with the notion of collective dance creation which acknowledges that a choreographic artwork is the result of several contributors instead of one single genius. However, here only humans have hitherto been granted the status of creative coproducers. I therefore propose to enlarge this human-centered scope to material actors with the help of Actor-Network-Theory (ANT). I explain that ANT allows to consider digital dance creation as a process in which human and non-human actors co-determine the course of a choreographic artwork's production by engaging with each other. This leads me to develop an analytical framework by referring to selected ANT-related concepts. The conceptual grid makes possible to trace the ways in which human and nonhuman participants, and thus also digital media, engage in dance-making procedures and co-shape the evolving dynamics, artistic intentions and results. It therewith permits to describe virtual media's creative agency in digital dance production.

Chapter 3 leads us to the rehearsal spaces of Habitat and loopdiver. Here I trace the evolution of these two digital dance productions by focusing on the formative role of virtual technologies in the rehearsal procedures. Recurring to the ANT-informed framework developed in chapter 2, I examine the dynamics in which the software programs Isadora (loopdiver) and Kalypso (Habitat) engage with the other (non-)human participants involved in the respective creative processes. I show that the tools' interactions with the other engaged actors generate diverse unexpected dynamics and frictions that directly and indirectly shape the artworks' development and final form on different levels. I also demonstrate that the technological tools themselves are equally 
affected during the creative process in different ways. My analysis therewith discloses an alternative perspective to dualistic viewpoints as it indicates that the rehearsal and creative procedures rather resemble moments of negotiation and continuous transformation in which neither of the participating actors remain the same.

Chapter 4 focuses on the status of new media in the bodily experience of digital dancers. I demonstrate that the relation between dancing bodies and (digital) technologies is often conceived in terms of domination, and that this binary understanding dates back to dualistic legacies of thought that emerged during earlier choreo-technical experiments in the 20th century. Claiming that these one-sided views do not allow to grasp the complexity of digital dancers' concrete physical sensations, I present a current alternative position that understands performing bodies and virtual media as comprised in processes of "relational dynamics". Scholars of this approach consider that contemporary dancing bodies find themselves in a fluctuating mode in which dancers' work with digital tools interferes with and reconfigures the performers' physical perceptions and movement sensations. While this physical condition is presented as a rather fluid procedure, I refer to dancers' reports to add that these "relational dynamics" include series of frictions and physical destabilization that emerge through the dancers' interaction with digital media. I identify these situations as significant because they generate the performers' bodily negotiation with the digital tools, and these learning procedures consequentially shape the dancers' physical experience. To render the notion of "relational dynamics" operable on a theoretical level, I subsequently develop a conceptual framework from theoretical approaches deriving from dance studies and postphenomenology that deal with the formation of dancing bodies, human-technology relations and the ways in which technologies infiltrate in bodily experience. The resulting interdisciplinary analytical toolkit, I argue, allows to describe situations of friction between dancing bodies and new media during digital dance rehearsals, to investigate the dancers' consequent negotiations with digital tools, and to explore how these learning procedures impact on the performers' physical sensations. I claim that articulating these processes makes possible to formulate the "relational dynamics" in digital dance and therewith to define a technology-inclusive understanding of bodily experience in virtual performance.

In chapter 5, we return to loopdiver's and Habitat's dance studios to examine how the digital performers concretely learn to dance with their digital devices. Here I specifically concentrate on the moments of friction between dancing bodies and virtual media to find out how the performers' physical disorientation is brought about, and on the consequences these situations of conflict have for the dancers' subsequent rehearsal activities and their bodily experiences. In Habitat and loopdiver, the performers undergo moments of disorientation while being confronted with digitally manipulated video reflections of their own bodies. With the help of the interdisciplinary conceptual toolkit 
elaborated in chapter 4, I show that during the subsequent rehearsal phases, the dancers undertake various activities to realign their inner bodily sensations and motoric capacities with their digitally modified video reflections. The two examples illustrate that these realignment strategies are influenced by the technologies' specific characteristics. By presenting and analyzing the performers' particular readjustment activities, I find out that the employed media are involved on an imaginative, a didactic and perceptivekinaesthetic level in the dancers' bodily work and experience. I furthermore discover that also the tools themselves are adapted to the performers' physical and cognitive needs. Following the impact of these procedures, I notice that the moments of conflict and the ensuing negotiations with the technological devices impact on the performers' physical experience in the sense that they expand the dancers' bodily sensitivity, their movement vocabulary and bring the performers to develop new motoric capacities. Describing the "relational dynamics" in digital dance therewith allows to disclose different ways in which digital technologies can mediate physical experience in virtual performance, which I argue presents an alternative perspective to dualistic viewpoints in which digital media and dancing bodies are considered to dominate each other.

Chapter 6 finally concludes by discussing the findings of this research project and providing a perspective for further investigations in the field of digital dance and performance studies in general. 


\section{Samenvatting}

In dit proefschrift bestudeer ik digitale danscreatieprocessen door de lens van de technische mediatietheorie. Met deze benadering beoog ik een alternatieve kijk op choreo-technische netwerken te creëren. Deze benadering wijkt af van de meer conventionele stellingnames, waarbij de verhouding tussen dans en digitale media wordt beschreven met begrippen zoals tegenstelling of dominantie. In die zin sluit ik aan bij een aantal onderzoekers van digitale performancekunsten, die een te eenzijdig begrip van digitale dans proberen te voorkomen door een meer relationele benadering van technologie. De vragen die deze studie uiteindelijk beoogt te beantwoorden zijn: Hoe werken dansartiesten en digitale media samen bij de creatie van digitale dansvoorstellingen? Wat is de rol van technologie hierin? En: hoe kan de dynamiek van dergelijke processen worden beschreven?

In plaats van te vertrekken vanuit een perspectief dat onderscheid maakt tussen danskunst enerzijds en media anderzijds, richt ik mij op hun verwevenheid en situatieve conditie. Ik baseer mijn studie op een definitie van (digitale) technologie die werd ontwikkeld in het domein van de wetenschap- en techniekstudies (Science and Technology Studies - STS). In STS wordt technologie niet alleen als materieel artefact, maar ook als socio-technisch netwerk gezien. Dit betekent dat STS-wetenschappers technologie beschouwen als reeds onderdeel uitmakend van socio-culturele contexten. Vanuit dit perspectief kunnen technologieën dan ook niet losgekoppeld worden van menselijke en sociale processen. Dergelijke STS-gerelateerde theorieën suggereren dat het beschouwen van digitale danscreatie als mediatieproces, het mogelijk maakt om de complexe dynamiek van virtuele performance nader te onderzoeken. In dit onderzoek stel ik derhalve voor om bepaalde STS-gerelateerde benaderingen van mediatie, zoals Actor-Netwerk Theorie (ANT) en postfenomenologie, evenals concepten uit de performancestudies te verbinden met recent onderzoek naar digitale performancekunst.

Dit proefschrift beschouwt de empirische realiteit van digitale dans aan de hand van concrete praktijkvoorbeelden. Hier zien wij hoe danskunstenaars en virtuele hulpmiddelen kennismaken, met elkaar in onderhandeling gaan en zich uiteindelijk vermengen. De focus ligt op de productie van twee virtuele danskunstwerken: loopdiver (2009) van de Amerikaanse dansgroep Troika Ranch, en Habitat (2010) van het Duitse collectief LaborGras. Door zich te verdiepen in de manier waarop digitale danskunstenaars de schemerzone tussen dans en media navigeren, gaat dit proefschrift in op de concrete uitdagingen waarmee digitale dansmakers worden geconfronteerd wanneer zij digitale performancekunst ontwikkelen, repeteren en opvoeren. Laverend tussen de gedetailleerde en materiele creatieprocessen van de uitvoeringen en mijn 
interdisciplinaire theoretische kaders, ontwikkel ik empirisch gevoelige modellen om de rol van technologie in digitale dansproductie te kunnen begrijpen. Geleid door de urgentie en relevantie voor zowel de artistieke praktijk als het digitale dansdebat, concentreer ik mij in het bijzonder op de creatieve dynamiek tussen danskunstenaars en digitale hulpmiddelen, alsook op de fysieke ervaring van de dansers tijdens hun interactie met digitale media. In verband met het eerste punt formuleer ik de volgende deelvragen: Op welke manier kunnen technologische hulpmiddelen invloed hebben op de artistieke dynamiek van danscreatie? En op welke manier kan deze betrokkenheid mede vormgeven aan artistieke intenties en de resulterende optredens? Om het tweede punt te onderzoeken vraag ik: Hoe integreren media lichamelijke ervaring in (digitale) dans?

In dit proefschrift is gekozen voor een empirische benadering door te analyseren hoe danskunstenaars omgaan met virtuele media tijdens het creëren van digitale voorstellingen. Ik heb hierbij in het bijzonder gebruik gemaakt van etnografische onderzoeksmethodes zoals interviews en participerende observatie vanuit een technografisch perspectief. Dit betekent dat ik niet alleen de menselijke actoren zoals danskunstenaars, multimediaprogrammeurs of technici gevolgd heb, maar ik heb ook de manieren bestudeerd waarop de technologische hulpmiddelen met die geobserveerde praktijken verbonden zijn.

Na een introductie van het onderzoek en de onderzoeksopzet in hoofdstuk 1, laat ik in hoofdstuk 2 zien dat binnen het werkveld van digitale dans zowel kunstenaars als wetenschappers vooringenomen zijn ten opzichte van de rol van technologie bij virtuele performancecreatie. Ik beargumenteer dat deze perspectieven onverenigbaar zijn met de empirische realiteit van digitale dansproductie omdat ze geen enkele creatieve slagvaardigheid toekennen aan technologische hulpmiddelen. Om een gedifferentieerde conceptuele zienswijze te ontwikkelen voor de manier waarop digitale media de artistieke aspekten van digitale dansproductie integreren, begin ik met de notie van collectieve danscreatie. Volgens dit concept moet een choreografisch kunstwerk gezien worden als het resultaat van meerdere medewerkers, en niet van een enkel genie. Evenwel hebben tot nu toe enkel menselijke deelnemers de status van creatieve coproducenten ontvangen. Mijn voorstel is daarom deze mens-gecentreerde focus met behulp van ANT, de acteur-netwerk theorie, uit te breiden naar materiële acteurs. Ik leg uit dat ANT toestaat om digitale danscreatie als een proces te zien, waarbij menselijke en niet-menselijke acteurs het productieproces van een choreografisch kunstwerk door hun interactie samen weten te bepalen. Hierbij heb ik vervolgens een analytisch kader ontwikkeld van met behulp van bepaalde ANT-gerelateerde concepten. Dit analytisch raamwerk maakt het mogelijk om de wijze te definiëren waarop menselijke en nietmenselijke deelnemers, en daarmee dus ook digitale media, participeren in danscreatie en hoe zij daarbij mede vormgeven aan de veranderende dynamiek, artistieke intenties 
en de uiteindelijke resultaten. Hierdoor is het mogelijk om de creatieve slagvaardigheid van virtuele media bij de productie van digitale dans te beschrijven.

Hoofdstuk 3 leidt ons naar de repetitieruimtes van Habitat en loopdiver. Hier volg ik de ontwikkeling van deze twee digitale dansproducties door mij te richten op de vormgevende rol van virtuele technologieën tijdens de repetitieprocessen. Teruggrijpend naar het ANT-geïnformeerd raamwerk dat ik in hoofdstuk 2 heb ontwikkeld, bestudeer ik het dynamisch proces waarbij de softwareprogramma's Isadora (loopdiver) en Kalypso (Habitat) omgaan met de andere (niet-)menselijke deelnemers tijdens de verschillende creatieve processen. Ik laat zien dat de interactie tussen de hulpmiddelen en de andere deelnemers onverwachte dynamiek en wrijving genereert. Deze processen modelleren op hun beurt op zowel directe als indirecte wijze de ontwikkeling en uiteindelijke vormgeving van het kunstwerk op verschillende niveaus. Ik laat ook zien hoe de technologische hulpmiddelen zelf op verschillende manieren worden beïnvloed gedurende het creatieve proces. Mijn analyse onthult daarmee een alternatief voor bestaande dualistische gezichtspunten, omdat het laat zien dat de repetitie- en creatieve processen juist op onderhandelings- en transformatiemomenten lijken waarbij geen van de deelnemers hetzelfde blijft.

Hoofdstuk 4 concentreert zich op de rol van nieuwe media in de lichamelijke ervaring van digitale dansers. Ik laat zien dat de relatie tussen dansende lichamen en (digitale) technologieën vaak in termen van dominantie gegoten wordt. Deze binaire zienswijze komt voort uit een dualistisch gedachtengoed dat is ontstaan ten tijde van choreo-technische experimenten in de 20e eeuw. Omdat dit perspectief het onmogelijk maakt om de complexiteit van de fysieke sensaties van digitale dansers te begrijpen, stel ik een nieuwe, alternatieve zienswijze voor. Hierbij worden uitvoerende lichamen en virtuele media opgevat als onderdeel van "relationele dynamiekprocessen". Immers, eigentijdse dansende lichamen bevinden zich in een fluctuerende toestand, waar de interactie met digitale hulpmiddelen de fysieke sensaties van dansers beïnvloedt en herconfigureert. Terwijl deze fysieke toestand hier als een vloeiend proces beschreven wordt, verwijs ik juist naar de ervaringen van dansers om aan te tonen dat deze "relationele dynamiek" ook situaties behelst van wrijving en lichamelijke destabilisatie. Deze situaties ontstaan door de interactie van de dansers met digitale media. Ik merk deze situaties aan als veelbetekenend omdat zij een lichamelijke onderhandeling teweegbrengen tussen de dansers en de digitale hulpmiddelen. Bijgevolg geven deze leerprocessen vorm aan de fysieke ervaring van de dansers. Om het idee van "relationale dynamiek" op een theoretisch niveau operationeel te maken ontwikkel ik een conceptueel raamwerk aan de hand van theorieën uit dansstudies en postfenomenologie. Deze theorieën houden zich bezig met de vorming van dansende lichamen, menstechnologie relaties en de manieren waarop technologieën binnendringen in fysieke ervaringen. Het resulterend interdisciplinair analytisch kader maakt het mogelijk om 
situaties van wrijving te beschrijven, die gedurende digitale dansrepetities ontstaan tussen dansende lichamen en nieuwe media. Bovendien staat het toe om de daaropvolgende onderhandelingen tussen de dansers en de digitale hulpmiddelen te bestuderen, en vervolgens te verkennen hoe deze leerprocessen de fysieke sensaties van dansers beïnvloeden. Ik beargumenteer dat het dankzij het beschrijven van dergelijke processen mogelijk wordt om de "relationele dynamiek" in digitale dans te verwoorden, en op die manier een technologie-inclusief begrip van lichamelijke ervaring in virtuele voorstellingen te definiëren.

In hoofdstuk 5 gaan we terug naar de dansstudio's van loopdiver en Habitat om te onderzoeken hoe dansers op concrete wijze leren om op te treden met hun digitale apparaten. Hier let ik in het bijzonder op de momenten van wrijving tussen de dansende lichamen en de virtuele media om te ontdekken hoe een fysieke desoriëntatie van de dansers ontstaat. Ook kijk ik naar de invloed van deze conflictsituaties voor de daaropvolgende repetetitieactiviteiten van de dansers en hoe zij dit lichamelijk beleven. De dansers in Habitat and loopdiver raken gedesoriënteerd wanneer zij met digitaal gemanipuleerde videobeelden van hun eigen lichamen geconfronteerd worden. Met behulp van het interdisciplinaire raamwerk uit hoofdstuk 4 laat ik zien hoe de dansers tijdens de volgende repetitiefasen op verschillende manieren proberen om hun innerlijke fysieke sensaties en motorische vaardigheden in balans te brengen met hun digitale projecties. De twee voorbeelden uit de praktijk illustreren hoe deze aanpassingsstrategieën worden beïnvloed door de specifieke eigenschappen van de verschillende technologieën. Door te omschrijven en te analyseren hoe de dansers zich elk op hun eigen wijze weten aan te passen, toon ik aan hoe de gebruikte media een verbintenis aangaan met het lichamelijke werk en de belevenis van de dansers op zowel een fantasierijk, didactisch en perceptief-kinesthetisch niveau. Ik laat ook zien ook dat zelfs de hulpmiddelen zelf worden aangepast aan de fysieke en cognitieve behoeften van de dansers. Uit het volgen van deze processen blijkt dat de conflictmomenten en de daaropvolgende onderhandelingen met de technologische apparaten de fysieke beleving van de dansers beïnvloeden, in die zin dat ze de lichamelijke sensibiliteit en het bewegingsvocabulaire van de dansers uitbreiden en de dansers ertoe aanzetten om nieuwe motorische vaardigheden te ontwikkelen. Het beschrijven van de "relationale dynamiek" in digitale dans maakt het derhalve mogelijk om verschillende manieren bloot te leggen waarop digitale technologieën als bemiddelaar kunnen optreden bij de fysieke ervaring in virtuele performance. Ik betoog dat deze manier van kijken naar digitale dans een alternatief biedt voor bestaande dualistische zienswijzen waar digitale media en dansende lichamen beschouwd worden als onderling dominerend.

Hoofdstuk 6 sluit af met een discussie van de onderzoeksresultaten en biedt perspectief voor verder onderzoek naar digitale dans en performancestudies. 